\title{
EVALUATION OF THE STRESS OF TRANSPORTING BROILER CHICKENS IN IRAQ ON SOME PRODUCTIVE, PHYSIOLOGICAL AND ECONOMIC CHARACTERISTICS
}
A. H. Al- obaidy*
A. Q. Shanoon**
Lect.
Prof.
D. H. Al-Hassani $* * *$
Prof.

* Department of Animal Produc. Coll. Agriculture, University of Diyala, ** Department of Animal Produc. Coll. Agriculture, University of Kirkuk, *** Animal production Dept., Coll.

Agric. Engin. Sci., University of Baghdad,

\section{ABSTRACT}

email: alhassani.dihya@yahoo.com, email: alalobiady@uodiyala.edu.iq

This experiment aimed for evaluating the stress and financial losses resulting from transporting broiler chickens from farms to slaughterhouses under harsh Iraqi conditions. Data were collected from 18 farms, where 42,564 broiler chickens were transported to slaughterhouses. Depending on the time of journey, the marketed birds were divided into three groups: short-time (T1), medium-time (T2), and long-time (T3) that lasted 3, 6, and 9 hours, respectively. The total percentage of mortalities resulting from transporting broiler was $0.46 \%$, while the percentage of lost weight was $\mathbf{5 . 1 2 \%}$, thus the percentage of total losses resulting from transportation reached $5.58 \%$. The overall percentage of mortalities and the percentage of lost weight increased with the increase transport period, as the percentage of mortality reached $0.08,0.31$ and $0.71 \%$, while the percentage of lost weight amounted to $3.84,5.12$ and $5.63 \%$ when transporting broilers for 3,6 and 9 hours, respectively. The financial losses resulting from the transport of broiler amounted to 12.627.275 Iraqi dinars, and the transport process led to a significant $(P \leq 0.01)$ increase in body temperature, $H / L$ ratio, glucose and aspartate transaminase (AST) and alanine transaminase (ALT) enzymes in blood serum and highly significant (P $\leq 0.01)$ decrease in packed cell volume, hemoglobin concentration, cholesterol, triglycerides and uric acid. It is concluded that the transportation of broiler chickens in Iraq is very stressful and causes financial losses that exceed international rates.

Keywords: high temperature, broiler, H/L, hemoglobin, packed cell volume

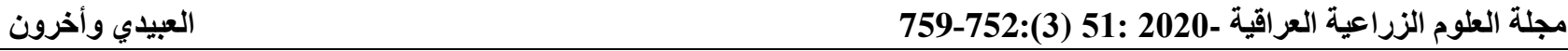

$$
\begin{aligned}
& \text { تقييم اجهاد نقل فروج اللحم في العراق على بعض الصفات الانتاجية و الفسلجية والاقتصاديه }
\end{aligned}
$$

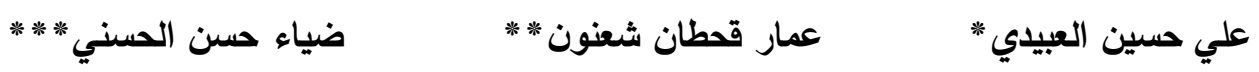

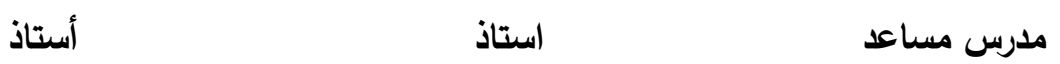

$$
\begin{aligned}
& \text { *قسم الانتاج الحيواني، كلية الزراعه، جامعة ديالى، ** قسم الانتاج الحيواني، كلية الزراعه، جامعة كركوك، *** قسم } \\
& \text { الانتاج الحيواني، كلية علوم الهندسه الزراعيه، جامعة بغداد }
\end{aligned}
$$

هدفت التجربة تقييم الاجهاد والخسائر المالية الناتجة عن نقل فروج اللحم من الحقول الى المجازر تحت ظروف العرلق القاسيه. جمعت البيانات من 18 حقل فروج لحم حيث سوقت 42564 فروجة لحم الى المجازر و اماكن البيع المفرد. قسمت الطيور المسوقه بالاعتماد

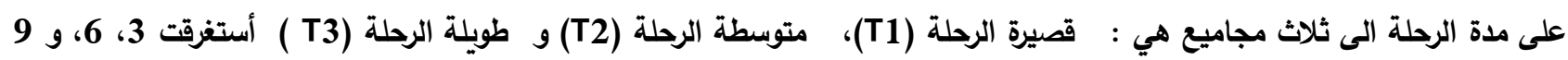
ساعات على التوالي. بلغت النسبة المئوية الكلية للهلاكات الناتجة عن نقل فروج اللحم 0.46 \% و نسبة الوزن المفقود 5.12 \% و بذلك بلغت نسبة الخسائر الكلية الناتجة عن النقل 58.58 \%. و ازدادت النسبة المئوية الكلية للهلاكات و نسبة الوزن المفقود بازدياد مدة النقل اذ بلغت نسبة الهلاكات 0.08 و 0.31 و 0.71 \% اما النسبة المئوية للوزن المفقود فقد بلغت 3.84 ، 5.12 و 5.63 \% عند نقل فروج اللحم للمدد 3، 6 و 9 ساعه على التوالي. بلغت الخسائر المالية الناتجة عن نقل فروج اللحم 12.627.275 دينار

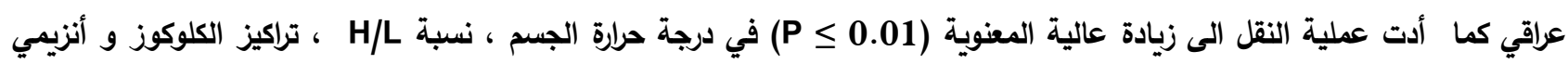
alanine transaminase aspartate transaminase في مصل الام و أنخفاض عالي المعنوية (P (P) في حجم خلايا الام المرصوصة ، الهيموغلوبين ، الكولسترول ، الكلسريدات الثلاثية و حامض اليوريك. يستنتج ان عمليات نقل فروج اللحم في العرلق مجهده جدا و تسبب خسائر اقتصاديه تفوق المعدلات العالميه. الكلمات المفتاحيه: ارتفاع الحراره، فروج اللحم، نسبة الخلايا المتغايره/ الخلايا اللمفيه، الهيموغلوبين، حجم الخلايا المضغوطه 


\section{INTRODUCTION}

The poultry industry is one of the main pillars for providing food to the world's population(24). The demand for poultry egg and meat products will increase as a result of the increase in the number of people in the world during the coming years, which may reach 8 billion in 2030. The process of transporting broilers to slaughterhouses is one of the main and important links in the chain of poultry industry, during which birds are exposed to several Stressful factors such as operations of handling, crowding, fear, vibrations, noise, hunger and thirst as well as changes in temperature and humidity $(2,9$, 22). All these factors and their interaction negatively affect productive efficiency and lead to exposure of birds to severe stresses that weaken the immunity and increase the numbers of dead birds and weight loss and low nutritional value and quality of meat produced as a result of wounds, fractures, bruises and drought, and thus increase economic losses (22). Bywater and others (13) reported that birds lose about $0.2-0.5 \%$ of their weight per hour during transport. The percentages of losses during transportation vary between $0.25,0.35,0.41$, and $0.46 \%(9,11,23,32)$. The percentage of deaths increases with the increase in transportation times and the increase in temperatures to reach $1-2 \%$ during the summer months (22). The operations of transporting birds especially broiler chicken in Iraq are not practically and scientifically correct, as it lacks modern transport and a specialized vehicles for transporting birds, in addition to high temperatures in most days of the year, which increases the stress incurred by the chicks $(6,7,18,19)$ and thus high economic losses. To our knowledge, no field and scientific study was conducted until now in Iraq, and accordingly this study was conducted.

\section{MATERIALS AND METHODS}

This experiment was conducted during the period between $1 / 15$ - 4/6/2018 on 42564 Ross 308 broiler chickens at the marketing age, obtained from 18 poultry farms in Diyala Governorate on the day of marketing. The birds were placed in plastic cages for the transport of broiler chickens, and the birds were transported by Hino vehicles. Depending on the journey time, the birds were divided into three groups: T1- group of birds transported for three hours and by five trips, T2- group of birds transported for six hours and by five trips and T3- group of birds transported for nine hours and by eight trips. During the transport process, hourly temperatures and humidity were recorded using the Chinese TCH-4 Mini electronic thermometer. Figure $\mathbf{1}$ shows average temperatures and humidity during trips. The birds were weighed before and after the transport and calculated the lost weight and the percentage of loss and the number of dead birds and their percentage using the following equations: lost weight during transportation = weight before transportation - weight after transportation, lost weight ratio $=$ lost weight during transportation / weight of birds before transportation $\times 100$, The number of dead birds $=$ the number of birds before transportation - the number of birds after the transfer, the mortality percentage $=$ the number of dead birds / the number of birds before the transport $\mathrm{x}$ 100. Economic losses are calculated on the basis of the price of $1 \mathrm{~kg}$ of live broiler chickens is 2,500 Iraqi dinars. 12 birds were chosen to estimate physiological characteristics, as the temperature was measured by inserting a TCH-4 Mini digital thermometer sensor into the rectal opening for a distance of $5 \mathrm{~cm}$. The packed cell volume was measured according to (10) and hemoglobin using the Drabkins Reagent product from Swiss company Agappe. The differential count of white blood cells was measured (12). Biochemical blood serum traits and activity ALT and AST enzymes were estimated according to the instructions of the German HUMAN producing Kits.Data were analyzed by using ready statistical analysis system (27) and the significant differences at $p$ $<0.05$ level (15).

\section{RESULTS AND DISCUSSION}

It is also noticed that the mortality increased with an increase in the transport duration time, as the group T1 recorded the lowest mortality, which amounted to $0.08 \%$, and the percentage increased to 0.31 and $0.71 \%$ in groups $\mathrm{T} 2$ and T3, respectively. Consequently, losses increased due to weight lost due to dead birds. Table 2 shows that the transport process led to 
a significant loss of body weight, as it reached $683 \mathrm{~kg}(3.84 \%)$ in Group T1, and the amount of loss increased to $1360 \mathrm{~kg}(5.12 \&)$ and 2592 $\mathrm{kg}(5.63 \%)$ in $\mathrm{T} 2$ and $\mathrm{T} 3$, respectively. Thus, the total weight loss was equal to $4,635 \mathrm{~kg}$, by $5.12 \%$ which is considered high compared to the global values $(20,21)$. The table reveals also that the single bird lost weight 0.073 , 0.101 and $0.109 \mathrm{~kg}$ in T1, T2 and T3 groups, respectively. Figure 2 shows the economic losses resulting from weight loss during the transportation of the broiler chickens, where it amounted to $1.707,500$ Iraqi dinars (ID) when transporting broilers for 3 hours, and the losses increased to $3,400,000$ and $6,480,000$ ID when transporting broilers for 6 and 9 hours respectively. The losses resulting from the dead birds also increased with the increase of the transport duration time, reaching 39075, 210.700 and 815.850 ID when transporting broilers for 3, 6 and 9 hours, respectively, and the total losses resulting from the dead birds amounted to 1,039.775 ID (Figure 3). Figure 4 exhibits the total economic losses resulting from weight loss during the transport broilers of the three groups from the rearing farms to the slaughterhouses and marketing places where the total economic losses reached $12,627,275$ ID at a rate of $5.58 \%$, while the losses amounted to $1.746 .575,3,610,700$ and 7.295.850 ID when transporting broilers for 3, 6 and 9 hours, respectively. Figure 5 shows the average total economic losses resulting from weight loss and dead birds, that amounted to 349315, 722140 and 911981.3 ID in groups $\mathrm{T} 1, \mathrm{~T} 2$, and $\mathrm{T} 3$ respectively, and the overall total is 702951.3889 ID. It is noted from Table 3 that the transport led to significant changes in the physiological traits and caused acute physiological stress, as the body temperature increased significantly $(\mathrm{P} \leq$ $0.01)$, also a significant $(\mathrm{P} \leq 0.01)$ decrease in packed cell volume (PCV), hemoglobin $\mathrm{Hb}$ concentration, lymphocyte percentage, and high significant $(\mathrm{P} \leq 0.01)$ increase in the heterophil cell percentage that caused a significant $(\mathrm{P} \leq 0.01)$ increase in heterophil / lymphocyte ratio $(\mathrm{H} / \mathrm{L})$. Rise of $\mathrm{H} / \mathrm{L}$ ratio is one of the important indicators reveals that birds exposed to sever physiological stress. Table 4 indicates that the transport process resulted in a highly significant increase $(\mathrm{P} \leq$
$0.01)$ in the concentration of glucose and a significant $(P \leq 0.01)$ decrease in the total protein concentration and the concentration of globulin while the albumin concentration was not affected. A significant $(\mathrm{P} \leq 0.01)$ decrease occurred in the concentration of uric acid, cholesterol and triglycerides, while AST ALT enzymes increased significantly. Weight loss is the main cause of economic losses, as it was found that $92 \%$ of the total economic losses are due to it, whereas losses due to dead birds accounted for $8 \%$ of the total losses in the experiment. There are several factors that affect weight loss, such as temperature, humidity, and fasting. The ideal temperature for transporting broilers is $20-22^{\circ} \mathrm{C}$ and 65 $70 \%$ relative humidity (22). The higher the temperature, the higher the weight loss rate ( 8, 34). As shown in Figure 1, extreme heat increase and low humidity That indicates the harsh conditions in which birds are transported in Iraq. An increase in ambient temperature leads to loss of body fluids and thus dehydration (31). Also, withdrawing food before transport while keeping water causes the crop and gut to be emptied, thereby reducing body weight $(17,26)$ and the birds are exposed during catch and loading to the stress that causes the absorption process in the small intestine to be stopped immediately (17). Fear and tough handling provokes the nervous system and increased excretion of dropping, as Taylor and others (30)found that Fear causes a loss of $1.8 \%$ of the live weight of broiler as a result of increased dropping during transport. The period between holding, placing birds in cages, loading and transporting them up to the slaughterhouse is considered one of the most dangerous periods for the life of the bird (9), as the total stressful factors that the bird is exposed to and the interference between them negatively affects the productive efficiency of the birds And increases the chance of being exposed to die as a result of a weakness and depression in immunity. Elrom (16), Chauvin and his colleagues (14) mentioned that $40 \%$ of the dead birds during transportation are due to stress, especially heat stress. Either the transfer and loading process leads to $35 \%$ of the total dead birds, or the cause of the dead may be to the heart failer or fear and shock, where Najdam and his colleagues (23) found that 
about\% 42.4 of the total mortality resulted from heart disorder, while the mortality due to fear and shock form about $28 \%$ of total mortality. The increase in the concentration of the corticosterone hormone as a result of stress leads to the destruction of immune cells, especially lymphocyte, which leads to an increase in the proportion of heterophil: lymphocyte ratio (1), and the reason for the decrease in hemoglobin and the packed cell volume as a result of transport may be due to the exposure of birds to acute stress $(3,29)$. as a result of interference between transport and high Temperatures and lack of water, which affects the process of Erythropoiesis , and consequently a decrease in the number of red blood cells, where there was a decrease in the number of red blood cells when the broiler exposed to thermal stress (4). The transport stress causes an increase in the levels of catecholamines, corticosteroids and glucagon In the blood. These hormones activate the glycogenolysis process, that increase the level of glucose in blood to provide the energy needed to fight stress, as well as the formation of glucose from non-carbohydrate sources through the process of gluconeogensis, and this is accompanied by a decrease in the formation of proteins and fats $(5,33,28)$. The reason for the increase in the effectiveness of ALT and AST enzymes in liver and their increased concentration in the blood may be due to cell destruction and tissue breakdown, and thus the transmission of these enzymes to the blood. The effectiveness of these enzymes is higher in Erythrocytes than in plasma or serum, so Hemolysis leads to an increase in the activity of these enzymes, which can be inferred by a decrease in the hemoglobin concentration and packed cell volume, or the reason for their high concentration may be due to high temperatures (25). The results showed the magnitude of the losses resulting from the transport of very stressful broiler chickens in Iraqi conditions.

Table 1. Mortality and weight loss resulting from the transport of broiler from farms to slaughterhouse

\begin{tabular}{|c|c|c|c|c|c|}
\hline \multirow{2}{*}{ Treatment } & $\begin{array}{c}\text { Number of } \\
\text { Journeys }\end{array}$ & $\begin{array}{c}\text { Weight before } \\
\text { journey }(\mathbf{k g})\end{array}$ & $\begin{array}{c}\text { Weight after } \\
\text { journey(kg) }\end{array}$ & $\begin{array}{c}\text { Weight Loss } \\
(\mathrm{kg})\end{array}$ & $\begin{array}{c}\text { Weight Loss } \\
(\%)\end{array}$ \\
\hline T1 & 5 & 17776 & 17093 & 683 & 3.84 \\
T2 & 5 & 26552 & 25192 & $\mathbf{1 3 6 0}$ & $\mathbf{5 . 1 2}$ \\
T3 & 8 & 46031 & 43439 & 2592 & 5.63 \\
\cline { 2 - 7 } total & 18 & 90359 & 85724 & 4635 & 5.12 \\
\hline
\end{tabular}

*In this table and succeeding tables $\&$ figures, treatments T1, T2 and T3 mean birds transported for 3, 6 and 9 hours respectively.

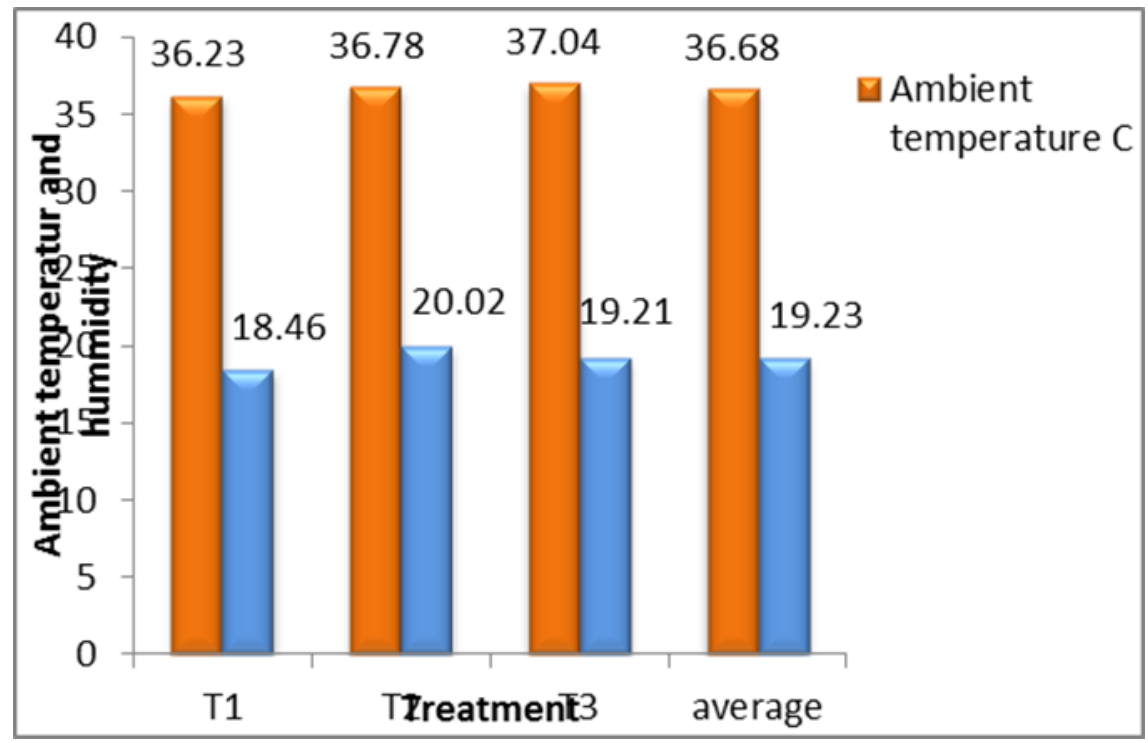

Figure 1. Average of temperatures $\left({ }^{0} \mathrm{C}\right)$ and relative humidity $(\%)$ recorded during journeys of experiment 
Table 2. Weight loss (kg) due to broilers transported from farms to slaughterhouse

\begin{tabular}{|c|c|c|c|c|c|c|}
\hline *Treatments & $\begin{array}{c}\text { Number of } \\
\text { journeys }\end{array}$ & $\begin{array}{l}\text { Number of } \\
\text { Transported } \\
\text { birds }\end{array}$ & $\begin{array}{l}\text { Number of } \\
\text { arrived } \\
\text { birds }\end{array}$ & $\begin{array}{c}\text { Number of } \\
\text { Dead } \\
\text { birds } \\
\end{array}$ & $\begin{array}{l}\text { Mortality } \\
(\%)\end{array}$ & $\begin{array}{l}\text { weight loss } \\
\text { (Kg) }\end{array}$ \\
\hline T1 & 5 & 9096 & 9088 & 8 & 0.08 & 15.63 \\
\hline $\mathbf{T} 2$ & 5 & 12600 & 12560 & 40 & 0.31 & 84.28 \\
\hline T3 & 8 & 20868 & 20720 & 148 & 0.71 & 326.34 \\
\hline Total & 8 & 42564 & 42368 & 196 & 0.46 & 415.91 \\
\hline
\end{tabular}

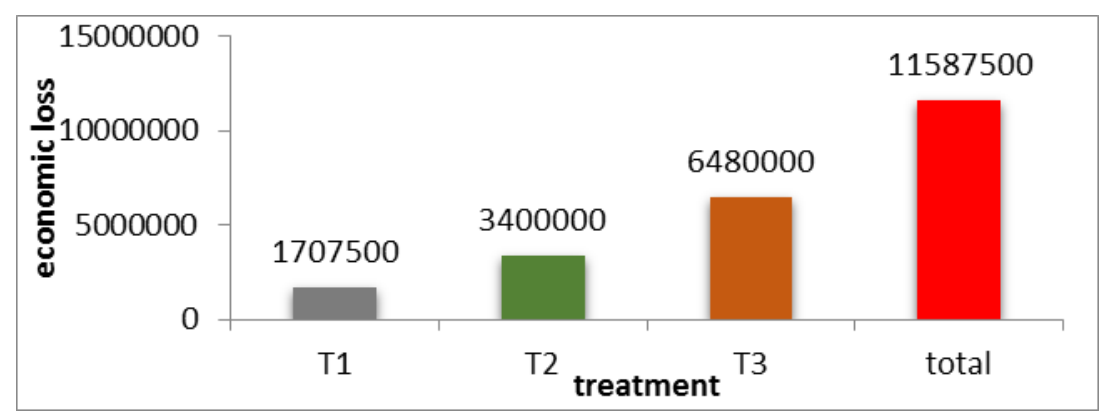

Figure 2. Economical losses due to weight loss throughout broiler Transportation (1 $\mathrm{kg}$ of live body weight equals to 2500 Iraqi Dinars)

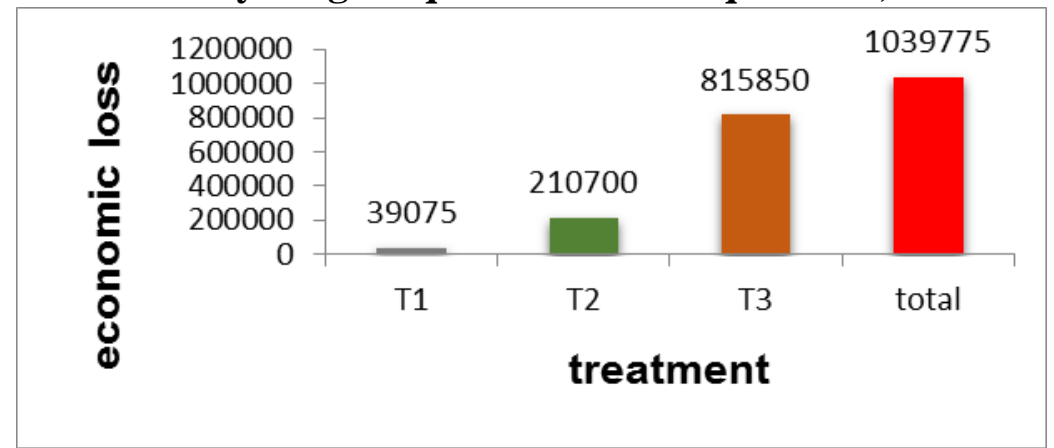

Figure 3. Economical losses due to mortality throughout broiler transportation

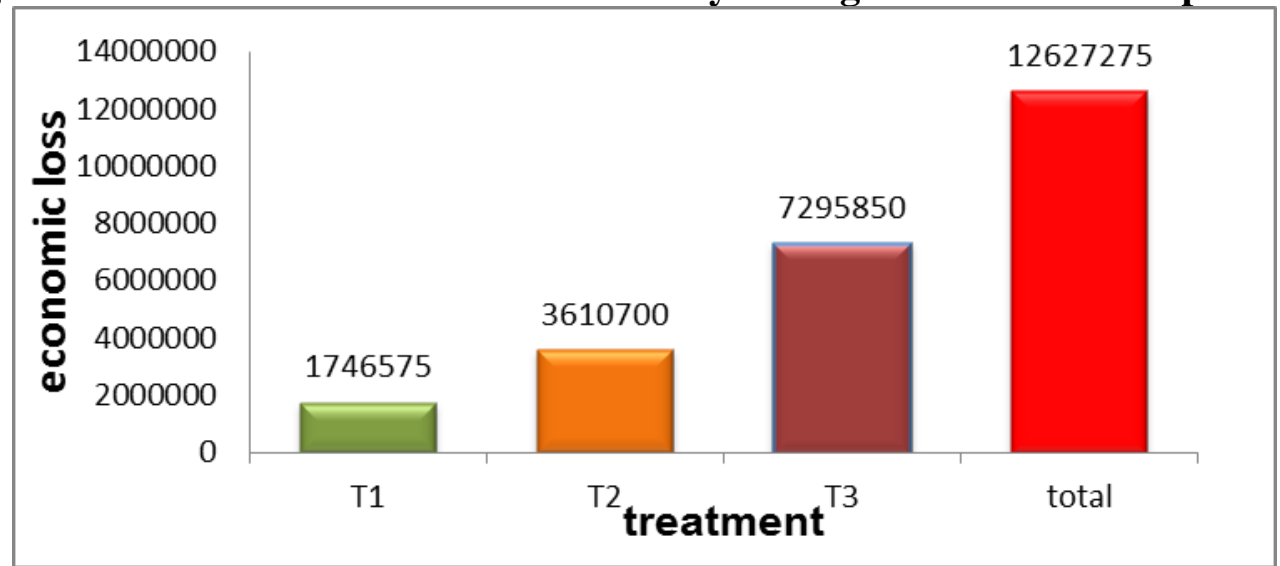

Figure 4. Economical losses due to weight loss and weight of dead birds during transportation 


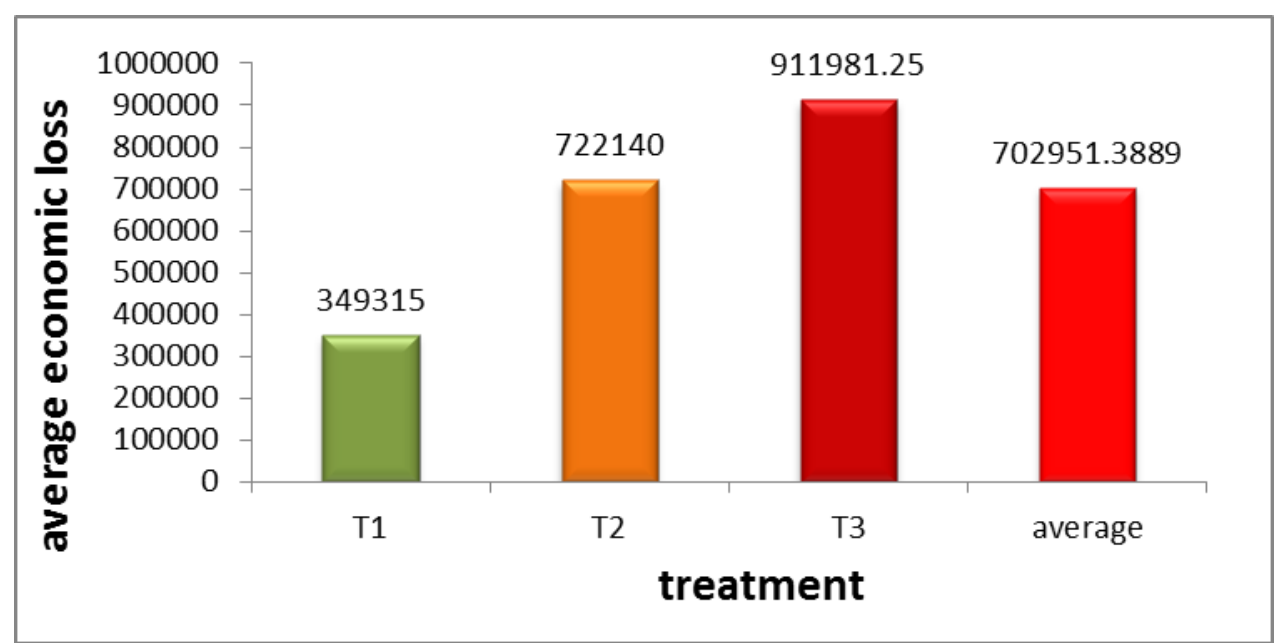

Figure 5. Average Economical losses due to each transportation journey

Table 3. Effect of transportation of broiler chickens from farms to slaughterhouses on some blood traits

\begin{tabular}{|c|c|c|c|}
\hline TRAITS & $\begin{array}{c}\text { BEFORE } \\
\text { TRANSPORTATION }\end{array}$ & $\begin{array}{c}\text { AFTER } \\
\text { TRANSPORTATION }\end{array}$ & P-VALUE \\
\hline body temperatures $\left({ }^{\circ} \mathrm{C}\right)$ & $41.50 \pm 0.11$ & $42.99 \pm 0.07$ & $* *$ \\
\hline PCV \% & $37.00 \pm 0.99$ & $31.70 \pm 0.20$ & $* *$ \\
\hline Hb gm $/ 100 \mathrm{ml}$ & $11.49 \pm 11.49$ & $10.12 \pm 0.21$ & $* *$ \\
\hline H\% & $33.40 \pm 33.40$ & $42.10 \pm 0.45$ & $* *$ \\
\hline $\mathbf{L} \%$ & $\mathbf{5 7 . 7 0} \pm \mathbf{5 7 . 7 0}$ & $49.00 \pm 0.39$ & $* *$ \\
\hline H/L & $0.61 \pm 0.01$ & $0.85 \pm 0.013$ & $* *$ \\
\hline
\end{tabular}

$* *=\mathbf{p}<\mathbf{0 . 0 1}=$ highly significant difference

Table 4. The effect of transport stress on blood serum traits of broiler chickens. (mean \pm S.E)

\begin{tabular}{|lccc|}
\hline \multicolumn{1}{|c}{ TRAITS } & BEFORE & AFTER & P-VALUE \\
\hline Glucose (mg/ dl) & $\mathbf{1 4 5 . 5 8} \pm \mathbf{5 . 4 4}$ & $\mathbf{1 8 7 . 7 8} \pm \mathbf{1 0 . 7 5}$ & $* *$ \\
Total protein (g/dl) & $4.24 \pm \mathbf{0 . 1 6}$ & $\mathbf{3 . 0 9} \pm \mathbf{0 . 1 6}$ & $* *$ \\
Albumin (g/l) & $2.71 \pm \mathbf{0 . 1 5}$ & $\mathbf{1 . 9 4} \pm \mathbf{0 . 1 5}$ & N.S \\
Globulin (g/l) & $\mathbf{2 . 0 7} \pm \mathbf{0 . 1 8}$ & $\mathbf{1 . 1 5} \pm \mathbf{0 . 1 6}$ & $* *$ \\
Uric acid (mg/l) & $9.74 \pm \mathbf{0 . 4 9}$ & $\mathbf{6 . 4 0} \pm \mathbf{0 . 5 1}$ & $* *$ \\
Cholesterol (mg/l) & $\mathbf{1 6 2 . 6 7 \pm 4 . 7 5}$ & $\mathbf{1 3 6 . 4 1} \pm 10.68$ & $* *$ \\
Triglycerides (g/l) & $\mathbf{7 8 . 4 8 \pm 2 . 6 4}$ & $\mathbf{6 1 . 9 1} \pm \mathbf{5 . 4 6}$ & $* *$ \\
AST (IU/l) & $\mathbf{1 1 6 . 2 4} \pm \mathbf{0 . 7 8}$ & $\mathbf{1 2 6 . 8 4} \pm \mathbf{0 . 8 9}$ & $* *$ \\
ALT (IU/l) & $\mathbf{8 . 6 8} \pm \mathbf{0 . 2 8}$ & $\mathbf{1 2 . 0 5} \pm \mathbf{0 . 5 8}$ & $* *$ \\
\hline
\end{tabular}

$* *=\mathbf{p}<0.01=$ highly significant difference

\section{REFERENCES}

1. Abdul-latif, K. M., D. H. Al-Hassani and B.G.Al-Khatib. 2002. Effect of supplementation of different levels of vitamin E with drinking water on productive performance and immune response of broiler. Iraqi J. Agric. (special issue) 7(1): 48-55

2. Ajakaiye, J. J., J. O. Ayo and S. A. Ojo. 2010. Effects of heat stress on some blood parameters and egg production of Shika
Brown layer chickens transported by road. Biol. Res. J. 43(1): 183-189

3. Al-Asadi A.N. and D.H. Alhassani, 2008. Effect of chicken embryos injection by nutritive solutions and early feeding on some productive and physiological traits. Fayoum J.Agric.Res. \& Dev., 22(2): 19-28

4. AL-Ghabban, A.G.SH and D.H.ALHassani. 2020. Effect of season and sex on some productive traits of peckin duck reared intensively under Iraqi conditions. Iraqi 
Journal of Agricultural Sciences. 51(Special Issue): $116-123$

5. Alhassani, D.H. and A.N. Al-Asadi. 2009. Effect of in ovo injection by nutritive solutions and early feeding on lengths of digestive tract parts of broiler chickens. Alkufa J. for agric.sci. 1(2): 27-40

6. Alhassani, D.H and A.Y. Al-shukri. 2011. Effect of using different concentrations of betaine on some productive traits of broiler reared under high temperature. Kufa J. for Agriculture Science, 3(1): 164-171

7. Alhassani,D.H. and A. Al-Shukri. 2016. Comparative efficacy of different supplements with drinking water used to alleviate body temperature of heat-stressed broiler chickens. The Iraqi Journal of Agricultural Sciences. 47(Special Issue):12-18.

8. Al-shukri, A.Y and D.H Alhassani. 2012. Effect of betaine supplemented with drinking water on water intake pattern of broiler chickens exposed to heat stress. Journal of Tikrit University for Agriculture Sciences. 12(2): 107-115

9. Aral Y., M. S. Arikan and A. C. AKIN. 2014. Economic losses due to live weight shrinkage and mortality during the broiler transport . Ankara -Univ. Vet. Fak Derg. 61(2): 205-210.

10. Archer , R.K. 1965. Hematological Techniques for Use on Animals . Blackwell scientific publications Oxford .pp:231-239

11. Bianchi M., M. Petracci and C. Cavani. 2005. Effects of transport and lairage on mortality, live weight loss and carcass quality in broiler chickens. https://www.researchgate.net/publication/4139 $\underline{4134}$

12. Burton , R. R. and C. W. Guion. 1986 . The differential leucocyte blood count. It's Precision and individuality in the chicken. Poultry Sci. 47(12): 1945-1949

13. Bywater T.M. , J. G. Dingle and McGLDRICK. 2003. Comparison of weight loss of broilers transported on conventional or controlled environment trailers . Aust. Polt. Sci. Sym.(15):145-148

14. Chauvin C., S. Hillion, L. Balaine, V. Michel, J. Peraste, I. Petetin, C. Lupo and S. Le Bouquin. 2011. Factors associated with mortality of broilers during transport to slaughterhouse. Animal 5(2) 287-293
15. Duncan , D.B.1955 . Multiple ranges and multiple F-test . Biometrics 11: 1-42

16. Elrom, K. 2001. Handling and transportation of broilers; welfare, stress, fear and meat quality: Part V: Transport to the slaughterhouse. Israeli $\mathrm{J}$. of Vet. Medicine, 56(1) :1-3

17. Gomes H. A., S. L. Vieira, R. N. Reis, D. M. Freitas, R. Barros, F. V.F. Furtado, and P. X. Silva. 2008. Body weight, carcass yield, and intestinal contents of broilers having sodium and potassium salts in the drinking water twenty-four hours before processing $\mathrm{J}$. Appl. Poultry Res. 17(3) :369-375

18. Habeeb, G, R., D. H. Al-Hassani and I. H. Ismail, 2004 a. Effect of enzymes supplementation on some productive traits of broiler reared under hot climate. Iraqi J. Agric. Sci. 35(1): 141-144

19. Habeeb, G, R., D. H. Al-Hassani and I.H. Ismail. 2004 b. Effect of enzymes supplementation to broiler diet reared under hot climate on some blood traits. Iraqi $\mathrm{J}$. Agric. Sci. 35(4): 115-120

20. Jacobs, L., E. Delezie, L. Duchateau, K. Goethals, and F. A. M. Tuyttens. 2017. Impact of the separate pre-slaughter stages on broiler chicken welfare. Poultry Sci. 96(2): 266-273

21. Jiang, N. N., T. Xing, P. Wang, C. Xie, and X. L. Xu. 2015. Effects of water-misting sprays with forced ventilation after transport during summer on meat quality, stress parameters, glycolytic potential and microstructures of muscle in broilers. AsianAustral. J. Anim. Sci. 28(8):1767-1773

22. Mitchell, M. A., A.J. Carlisle, R.R. Hunter and P.J. Kettlewell. 2009. Welfare of poultry during transport - a review. Poultry Welfare Symposium Cervia, Italy, 18-22 may

23. Nijdam, E., Arens, P., Lamboij, E., Decuypere, E and Stegman, J.A. 2004. Factors influencing bruise and mortality of broilers during catching, transport and lairage. Poultry Sci. 83(10): 1610-1615

24. OECD/FAO. 2019. OECD-FAO Agricultural Outlook 2019-2028, OECD Publishing, Paris/Food and Agriculture Organization of the United Nations, Rome. https://doi.org/10.1787/agr_outlook-2019-en

25. Perai, A.H., H. Kermanshahi and H. Nassiri Moghaddam. 2014. Effects of supplemental vitamin $\mathrm{C}$ and chromium on 
metabolic and hormonal responses, antioxidant status, and tonic immobility reactions of transported broiler chickens. Biol Trace Elem. Res. 157(1): 224-233

26. Rosa Paulo Sérgio, C. T. Anildo, N. S. Gerson, S. Leticia dos, R. B. Edison and M. A. Neilor. 2012. Effect of broiler fasting time during pre-slaughter. World's Poultry Sci. J. 5(9):144-147

27. SAS Institute. 2000. SAS/STAT User's Guide, version 8, Volumes 1, 2 and 3. SAS Inst., Cary, NC

28. Scanes, C. G. 2015. Sturkie's Avian Physiology. $6^{\text {th }}$ Ed. Accademic Press. San Diego London Boston New York Sydney Tokyo Toronto. pp: 860-869

29. Schwartzkopf-Genswein K.S, L. Faucitano, S. Dadgar, P. Shand, L.A. González and T.G. Crowe. 2012. Road transport of cattle, swine and poultry in North America and its impact on animal welfare, carcass and meat quality: A review. Meat Sci. 92(1):227-243 30. Taylor NL, D.L. Fletcher, J.KJ. Northcutt, and M.P. Lacy. 2006. Effect of transport cage height on broiler live shrink and defecation patterns. J. Appl. Poultry Res. 10(2): 335-339
31. Vecerkova,L., V. Vecerek, and. Voslarova. 2019. Welfare of end-of-lay hens transported for slaughter: effects of ambient temperature, season, and transport distance on transportrelated mortality. Poultry Sci. 98(4): 62176224

32. Vecerek, V., S. Gralbova, E. Voslarova, B. Janackova and M. Malena. 2006. Effects of travel distance and the season of the year on death rates in broilers transported to poultry processing plants. Poultry Sci. 85(11): 18811884

33. Zhang, L., J. Li, T. Gao, M. Lin, X. Wang, X. Zhu and G. Zhou. 2014. Effects of dietary supplementation with creatine monohydrate during the finishing period on growth performance, carcass traits, meat quality and muscle glycolytic potential of broilers subjected to transport stress. Animal, 8(12): 1955-1962

34. Zhang L., * H. Huang, Y. P. Wang, T. Xing and $\mathrm{X}$. Xu. 2020. Water-spraying forced ventilation during holding improves the water holding capacity, impedance, and microstructure of breast meat from summertransported broiler chickens. Poultry Sci. 99(10): 1744-1749. 